\title{
Review
}

\section{Reading Marx}

\author{
Slavoj Žižek, Frank Ruda, and Agon Hamza \\ Polity, Cambridge/Medford MA, 2018, vi + 170pp., \\ ISBN: 978-1509521418
}

Contemporary Political Theory (2020) 19, S179-S182. https://doi.org/10.1057/s41296019-00321-3; Published online 16 April 2019

Reading Marx consists of a co-written introduction and conclusion, plus an unsigned essay by each of the authors, Slavoj Žižek, Frank Ruda, and Agon Hamza, in that order. The introduction, 'Unexpected Reunions', sets forth the aim of the book: to give distinct philosophical readings of Marx. The authors take this to mean that they will not celebrate Marx, defend him unconditionally, or dissect the living and dead elements of Marx's corpus, but 'read and thus think with Marx as a contemporary' (p. 3). This is a distinction without a difference, since to take the living elements of Marx's work is to treat his ideas as of contemporary significance. More significantly, the authors ground the need for a contemporary philosophical treatment of Marx in the closure of emancipatory possibilities engendered by the rise of authoritarian political and capitalist forms, which have severed the putative link between capitalism and democracy posited by Fukuyama's 'end of history' thesis (p. 4). I do not think that the authors have really said very much about these emancipatory possibilities, although they say a little about how the sphere of possibility has been reinterpreted to exclude alternatives to capitalism. On their account, Marxist philosophy can intervene in this history by demonstrating the modal conversion of specific historical impossibilities of radical political and economic transformation 'into a new possibility (of emancipation)' (p. 2). To demonstrate this capability, it is necessary first to recognize that Marxism is multivalent and that without its revolutionary force, it can become canonized, sacralized, and thereby disconnected from the present concrete situation (p. 5). Each of these aims is salutary but its promise unfulfilled. In fact, a great deal of the work of the text actually involves reading Marxist thought in(to) Hegel.

The first essay, 'Marx Reads Object-Oriented Ontology', is by Žižek, Professor at the Institute of Sociology, Ljubljana, Slovenia, and perhaps the most famous living philosopher. Žižek is particularly notable for his unexpected juxtapositions of Marxist-Hegelian philosophy with Lacan and popular culture. Here, he brings in Graham Harman's object-oriented ontology (a term coined by Levi Bryant), a recent neo-Heideggerian movement that overturns the primacy of subjects over

(c) 2019 Springer Nature Limited. 1470-8914 Contemporary Political Theory Vol. 19, S3, S179-S182 
objects and anthropocentric correlations of cognitive content with external reality to consider objects in other terms than human perception, praxis or activity (real vs. sensual objects). Žižek approaches this debate critically from the perspective of a philosopher whose analysis privileges subject-object dialectics. Yet, whatever the merits of object-oriented ontology may be, Žižek's continued reliance on a subjectobject ontology limits his ability here to offer genuine alternatives. He attempts to reconstitute subject-object relations performatively as they appear to themselves, while their " "material base" is just a neuronal-biological apparatus' (p. 50). Yet, he is trapped within this same restrictive opposition. Still, within this opposition, his claims remain interesting. The first concerns normativity. In his account, communism functions through the activity of involved subjects, yet its normativity requires that they treat the norms constituted by subjective activity as objective, and thus, as universal givens, despite the fact that those norms were freely, and thus contingently, enacted by autonomous subjects. Žižek's virtual philosophy of 'as if' makes psychological sense even if it sounds suspiciously like Sartrean bad faith, treating as objective what one knows is subjective. A second interesting claim is that Hegel should be read as a thinker of antagonism, rather than as a reductive universalist. Just as John Burbidge has argued that Hegel's absolute knowing is precisely the recognition of the necessarily relational, contingent or differential character of thinking, Žižek argues that the true or the totality is inherently defined as the whole by its contradictory, antagonistic, inconsistent nature (p. 44), and the necessary by its ineradicable contingency (p. 53). The key is that to forget the antagonisms - the radical core of emancipatory potential in a movement - is to lose that dimension that enables transcendence of the historical impossibility of a given time-bound moment.

The conclusion of the essay, that Harman's object-oriented ontology lacks the ability to articulate anything but passive subjects, is less valuable as a critique, because the demerits of thinking about persons as subjects are well-known and transcend the Lacanian critique. Nietzsche argued that subject-object thinking is inadequate both for its failure to interrogate the nature of thinking, the primacy of consciousness, and the nature of the self, and its reliance on the contingent metaphysics of grammar. Heidegger similarly argued to the tertiary character of subject-object relations, which he subordinated to the ontological difference, logos, and the synthesis-diaeresis of the logos apophantikos or demonstrative language. A first step in moving Hegelian-Marxist dialectics into the sphere of the contemporary for the purposes of advancing emancipatory discourse would be to think beyond capitalist subjects and objects in the constitution of such discourses in a more complex, concrete, and historically specific approach to human identity. Perhaps this thinking beyond and through subject-object dialectics would enable a more incisive rending of the veil than Žižek's example of seeing a reality through inhuman eyes in the unintended vision of the actors playing Siegmund and 
Sieglinde, still lying in an embrace behind a curtain suddenly parted after the end of Act I of Die Walküre (p. 52).

The second essay, 'Marx in the Cave', is by Ruda, a senior lecturer in philosophy at the University of Dundee. He begins with the highly suggestive idea that we might think of 'the history of critical and emancipatory thought (or philosophy) ... [as] nothing but footnotes to Plato's cave allegory' (p. 62). Specifically, what Ruda sees in the allegory is how unfreedom is naturalized in constituting humans 'in a non- or prehuman state' and forging shadowy illusions through mimesis and artistic representation, which preserve and engrain this unfreedom through their own actions (pp. 70-71). Now, the allegory of the cave as story of emancipation might be thought relevant to Marxist emancipatory thought in particular because it exhibits servitude as a socially conditioned, collective ignorance visited upon the oppressed by their slave masters; it regards emancipation as a collaborative process of education that involves understanding the essentially interconnected character of body and mind; and it mandates an essential role to critical philosophers able to recognize the difference between reality and popular ideology and to communicate this difference to the oppressed. There is much to say for this return to Plato's Republic, given its universal system of public education, abolition of private property among the ruling class, community of women and children, and critique of money and inequality, all of which are found in the Communist Manifesto as well. At the same time, we ought to remember that this comparison has been used as a means of condemning Marx, as well as Plato, by Karl Popper, among others, and there are stark and fundamental contrasts between Platonic idealism and Marxist materialism, between local Platonic aristocracy and Marxist industrial workers of the world. Indeed, Ruda's comparison is arguably a departure from Marx to Hegel, whose own idealist dialectical thinking, though distinct from the Platonic forms of idealism and dialectics, nonetheless, bears greater structural resemblance, certainly in the Science of Logic. While the history of emancipatory thought is deeply indebted to the allegory of the cave, we should not lose sight either of departures from Platonic emancipatory thinking or of the dangers of this relationship in thinking about Marx. Still, Ruda's thinking of capitalism's naturalization of an animalized worker whose time becomes the time of nature, abolishing historical time, provides a useful step toward a more radical conception of the entailments of capitalism on its workers.

The third essay is 'Imprinting Negativity: Hegel Reads Marx', by Hamza, a researcher at the Institute of Social Studies and Humanities in Tirana. All three essays see the project of a contemporary thinking of Marx, which is to say, a philosophy of Marx as a contemporary, as requiring a reading of Hegel, since Hegel is clearly and unambiguously a philosopher, but this last essay is most explicit in examining this question of how we might read Hegel to illuminate or advance thinking about Marx without merely selecting out from their context passages of Hegel that seem Marxist. Hamza characterizes Hegel's conception of labor in the

(c) 2019 Springer Nature Limited. 1470-8914 Contemporary Political Theory Vol. 19, S3, S179-S182 S181 
master-slave dialectic as providing a basis for an alternative Marxist theory by conceiving of alienated labor as characterized by a self-engendering servitude and fear that both perpetuate obedience and create a pathway to freedom precisely by exhibiting the worker's material constraints (p. 134). Knowledge of these material constraints enables recognition of one's objective oppression, and thus, of the possibility and need of emancipation. Of course, such a theoretical determination of the situation of the oppressed flies in the face of the actual non-resistance often exhibited by laborers, in particular the very worst off, a non-resistance that motivates Marxist ideology critique. Hence, such a determination does little to address the actual power imbalances that sustain the systems of authority and ideology that keep them in chains, literal or figurative.

While the conclusion does less to advance or synthesize these forms of thinking than to sum them up, Reading Marx ultimately is valuable in providing new ways of thinking about Marx, especially in relation to Hegel, as a means of reconceiving the theoretical foundations of Marxism. It also sheds light on just why we should not expect a clear program of political emancipation. Theory cannot leap ahead of historical praxis in such a way as to set forth the precise means of liberation because its precise character depends upon and is justifiable solely on the basis of the historical situation, which we cannot anticipate, and the historical actors, whose voices we should not attempt to silence in advance.

Publisher's Note Springer Nature remains neutral with regard to jurisdictional claims in published maps and institutional affiliations.

Joshua Rayman

University of South Florida, Tampa, FL 33620, USA jrayman@usf.edu 